\title{
Early Eocene frogs from Vastan Lignite Mine, Gujarat, India
}

Annelise Folie, Rajendra S. Rana, Kenneth D. Rose, Ashok Sahni, Kishor Kumar, Lachham Singh, and Thierry Smith

Acta Palaeontologica Polonica 58 (3), 2012: 511-524 doi: http://dx.doi.org/10.4202/app.2011.0063

The Ypresian Cambay Shale Formation of Vastan Lignite Mine in Gujarat, western India, has yielded a rich vertebrate fauna, including the earliest modern mammals of the Indian subcontinent. Here we describe its assemblage of four frogs, including two new genera and species, based on numerous, diverse and well-preserved ilia and vertebrae. An abundant frog, Eobarbourula delfinoi gen. and sp. nov., with a particular vertebral articulation similar to a zygosphene-zygantrum complex, represents the oldest record of the Bombinatoridae and might have been capable of displaying the Unken reflex. The large non-fossorial pelobatid Eopelobates, known from complete skeletons from the Eocene and Oligocene of Europe, is also identified at Vastan based on a single nearly complete ilium. An abundant "ranid" and a possible rhacophorid Indorana prasadi gen. and sp. nov. represent the earliest records of both families. The Vastan pelobatids and ranids confirm an early worldwide distribution of these families, and the bombinatorids and rhacophorids show possible origins of those clades on the Indian subcontinent.

Key words: Amphibia, Bombinatoridae, Ranidae, Pelobatidae, Rhacophoridae, Eocene, Vastan, India.

Annelise Folie [annelise.folie@ naturalsciences.be] and Thierry Smith [thierry.smith@naturalsciences.be ], Royal Belgian Institute of Natural Sciences, Department of Paleontology, Rue Vautier 29, B-1000 Brussels, Belgium; Rajendra S. Rana [rajendra.rana1@gmail.com ] and Lachham Singh [rawat.lachham@ yahoo.com], Department of Geology, H.N.B. Garhwal University, Srinagar 246175, Uttarakhand, India; Kenneth D. Rose [kdrose@jhmi.edu ], Center for Functional Anatomy and Evolution, Johns Hopkins University School of Medicine, Baltimore, Maryland 21205, USA; Ashok Sahni [ashok.sahni@gmail.com ], Centre of Advanced Study in Geology, Lucknow University, Lucknow 226001, India; Kishor Kumar [kumark@wihg.res.in], Wadia Institute of Himalayan Geology, 33 General Mahadeo Singh Road, Dehradun 248001, Uttarakhand, India. 
Attribution License (for details please see creativecommons.org), which permits unrestricted use, distribution, and reproduction in any medium, provided the original author and source are credited.

PoFif Full text $(809.3 \mathrm{kB})$ 